\title{
NATION-BUILDING VERSUS NATIONALISM: DIFFICULT DILEMMAS FOR THE CHURCH
}

\author{
Fr. Archim. Prof. Cyril HOVORUN, \\ Loyola Marymount University in Los Angeles \\ USA, \\ E-mail: serhiy.hovorun@yale.edu
}

\begin{abstract}
The article explores the phenomenon of nationalism in general and its Eastern Christian nuances in particular. It describes two major theories of nationalism: modernist and primordial. It also distinguishes between two stages of nationalism: emancipatory and oppressive. The former is healthier than the latter. The article focuses on the Orthodox editions of nationalism, which seemingly coheres with the traditional structure of local churches. In the Orthodox world, national particularity combined with ecclesial locality, can be either ethnic or civilizational. In the former case, it enhances a homogeneous national identity of the Balkan style. The latter case is an Orthodox neo-imperialism, which is incompatible with nation-building on the basis of one ethnicity. Their incompatibility often leads to conflicts and even wars.
\end{abstract}

Keywords: nation; civilization; identity; nationalism;

\section{INTRODUCTION}

Virtually all Orthodox churches are affected by nationalism to different degrees and in different forms. There are various types of nationalism in the modern Orthodox world. Some of them are quite civil, and some can be violent. Some nationalisms are particularist: they worship a nation in the narrow sense of the word. Others are more universalist: they profess supra-ethnic "civilizations." Many Orthodox Christians perceive their ethnic identity as sacred. In fact, however, it is quite profane and can be explained by the modern theories of nationalism.

There are two main theories of nationalism. According to one, nationalism is an exclusive product of the era of modernity. One of the earliest students of nationalism, Elie Kedourie, credited Kant and the Enlightenment for its emergence. ${ }^{1}$ Eric Hobsbawm connected the idea of nationalism with the emergence of capitalism. ${ }^{2}$ In his book Nations and Nationalism since 1780, he has traced the roots of nationalism back to the French revolution. ${ }^{3}$ Benedict Anderson pushed the origins of nationalism a bit earlier, to the print

\footnotetext{
* Presentation at the conference "Theology and Tradition, Spirituality and Modernity" at the "Valahia" University in Târgoviște, May 29-31, 2019.

${ }^{1}$ See Adrian Hastings, The Construction of Nationhood: Ethnicity, Religion, and Nationalism, (Cambridge; New York: Cambridge University Press, 1997), 10.

${ }^{2}$ See ibid.

${ }^{3}$ Eric J. Hobsbawm, Nations and Nationalism Since 1780: Programme, Myth, Reality, (Cambridge; New York: Cambridge University Press, 1990).
} 
revolution and the process of substitution of Latin with vernacular languages in Europe. ${ }^{4}$ Ernest Gellner suggested that modern nations never really existed, but were invented in the modern era. ${ }^{5}$

From the perspective of this theory, nationalism is coherent with ideology-another product of the modern era. Moreover, nationalism is probably the most powerful and longlasting version of ideology. ${ }^{6}$ Indeed, national identity has the same ideocratic nature as any ideology - the differentiation of ethnic groups is defined, in Benedict Anderson's words, only "by the style in which they are imagined."

The concept of nation was introduced to the modern political discourse by JeanJacques Rousseau. In the Projet de constitution pour la Corse (1765), he stated: "Every people has, or ought to have, a national character, and if it is lacking, one must begin by providing it to them." ${ }^{\prime 8}$ Although the idea of nation was articulated by a secular thinker, it soon became appropriated by Christian churches. The Frenchman abbé Sieyès (1748-1836) rendered the concept of nation in almost metaphysical terms: "The nation exists before everything, it is the object of everything. Its will is always legal, it is the law itself.",

Rousseau connected the concept of nation with his other idea, that of social contract. The social contract, as he envisaged it, shifted political authority from monarchs to people. This process disturbed the cohesion of a people. The concept of nation was supposed to reinforce the shaken cohesion. Peoples now had to be united not as subjects of a king, but as a "nation." By consolidating around their elected representatives, who exercised political authority not by God's will, but by the will of citizens, citizens were supposed to act as a "nation." The nation was understood as a common political space, to which all people belonged regardless of their birth, wealth, and religion. ${ }^{10}$ Nation became a source of political legitimacy for national governments, who functioned on behalf of a people.

The alternative theory of nationalism holds that its roots go deep to primordiality. ${ }^{11}$ Hugh Seton-Watson ${ }^{12}$, Doron Mendels ${ }^{13}$, and Susan Reynolds ${ }^{14}$ found the roots of some modern nations as early as in Antiquity. Indeed, one can see as paradigmatic for most modern national identities the following definition of Greeks by Herodotus: "There is the

\footnotetext{
${ }^{4}$ See Benedict Anderson, Imagined Communities: Reflections on the Origin and Spread of Nationalism, (London; New York: Verso, 2006), 39.

${ }_{6}^{5}$ Ernest Gellner, Thought and Change, (Chicago: University of Chicago Press, 1965), 168.

6 John Breuilly has called it "the most important political ideology of the modern era." John Breuilly, "Reflections on Nationalism", in Stuart Woolf, ed., Nationalism in Europe, 1815 to the Present: a Reader, (London: Routledge, 1996), 137.

${ }^{7}$ Anderson, Imagined Communities: Reflections on the Origin and Spread of Nationalism, 6.

${ }^{8} \mathrm{http} / / / \mathrm{www}$. constitution.org/jjr/corsica.htm [accessed April 9, 2019].

${ }^{9}$ Murray Greensmith Forsyth, Reason and Revolution: the Political Thought of the Abbé Sieyes, (Leicester; New York: Leicester University Press; Holmes \& Meier, 1987), 76.

${ }^{10}$ See Erica Benner, "Nationalism: Intellectual Origins," in John Breuilly, ed., The Oxford Handbook of the History of Nationalism, (Oxford: Oxford University Press, 2013), 39.

${ }^{11}$ See Peter Burke, "Nationalism and Vernaculars, 1500-1800," in ibid., 21.

${ }^{12}$ Hugh Seton-Watson, Nations and States: an Enquiry Into the Origins of Nations and the Politics of Nationalism, (Boulder, CO: Westview Press, 1977).

${ }^{13}$ Memory in Jewish, Pagan, and Christian Societies of the Graeco-Roman World, (London; New York: T \& T Clark International, 2004).

${ }^{14}$ Susan Reynolds, Kingdoms and Communities in Western Europe, 900-1300, (Oxford; New York: Oxford University Press, 1984).
} 


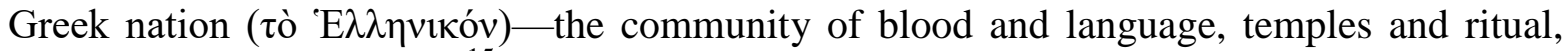
and our common customs." 15

There is apparently no much contradiction between the modern and premodern theories of nationalism, as premodern "nationalisms" can be seen as early forms of modern nationalisms. Probably it would be correct to call the former not "nationalisms," but "protonationalisms." They had a religious nature, in contrast to the modern nationalisms, which are secular in their nature.

A common feature of many proto-nationalisms was the idea of choosiness by God. Thus, long before the modernity Girolamo Savonarola (1452-1498) enchanted the Florentines with the idea that they are an "elect nation." The Reformation developed this idea further bestowing upon some "chosen nations" a mission to reform Christianity. As a result, German Lutheran, American Puritan, Scottish Presbyterian, and Dutch Reformed exceptionisms contributed to formation of corresponding nations.

Eastern proto-nationalisms also featured the idea of religious choosiness. However, in contrast to the Western mission to reform Christianity, they considered as their mission to preserve Christianity in its traditional forms. This is particularly the idea behind Greek, Romanian, Russian, and some other nationalisms. Orthodox nationalisms were also greatly inspired by the idea of preserving Byzantium. They can be called "meta-Byzantine" nationalisms.

Probably the earliest form of Eastern Christian proto-nationalism was doctrinal, when a theological movement turned to people's identity. Such was Arianism. It was a theological doctrine, which contributed to shaping a proto-national identity of a people - the Goths. Translation of the Bible to Gothic by the Arianising bishop Wulfila, contributed to the transformation of the doctrinal affiliation of the Goths to their cultural identity, which can be interpreted as proto-national. Arianism as a Gothic proto-national identity outlived Arianism as a theological doctrine.

Even more lasting proto-national identities were shaped by the theological controversies regarding the person and natures of Jesus Christ. In the beginning of the fifth century, a group of eastern Syrians adopted a teaching articulated by Theodore of Mopsuestia and promoted by the patriarch of Constantinople Nestorios. After this teaching was condemned by the Third ecumenical council of Ephesos (431) as "Nestorianism," many "Nestorians" moved to Persia. There, they mixed up with other religious dissidents from the Roman Empire. In the Sassanid Empire, the "Nestorian" confession gradually turned to a proto-ethnic identity of what is now known as the "Assyrian" people.

Soon after the council of Ephesos, the council of Chalcedon (451) decided that all Christians in the Roman Empire should recognize in Christ two natures and not one. However, many Egyptians and western Syrians disagreed with this decision. They formed confessional groups, which adopted the names of the leaders of dissent: "Theodosians" after the name of the Alexandrian Patriarch Theodosios (died 567), "Severans" after the Patriarch of Antioch Severos (465-538), and "Jacobites" after the bishop of Edessa Jacob Baradaeus (died 578). These groups built their identities upon the rejection of the council of Chalcedon. These identities gradually developed to ethnic ones: Copts, Syrians, Armenians, ${ }^{16}$ etc. Their

\footnotetext{
${ }^{15}$ Herodotus, Histories, 8.144.1-3, transl. by Aubrey de Sélincourt, (London: Penguin, 2003).

${ }^{16}$ Armenian national identity has become particularly strong. In the Pew research, it is on the top of the list of national identities connected with religion-82\% (Pew Research Center, "Religious Belief and National Belonging in Central and Eastern Europe," Pew Reserach Center, May 10, 2017,
} 
common denominator became the rejection of 1) the Greek language, 2) Roman rule, and 3) Chalcedonian Orthodoxy.

These three features, in their turn, transformed to the "Byzantine" proto-national identity. ${ }^{17}$ The Byzantines did not call themselves "Byzantines," but "Romans." This

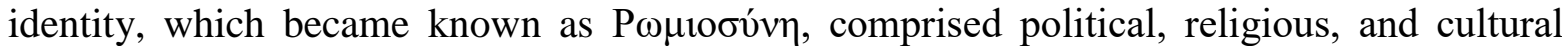
components. ${ }^{18}$ It by far survived Byzantium.

The Roman identity thrived in the Ottoman period. The non-Muslim religious minorities were organised to politically semi-autonomous groups called millets. The principle of organisation of these groups was religious: Yahud milleti included all Jews, millet-i Ermeniyan - all non-Chalcedonians; millet-i Rûm - all Chalcedonians, and the latest, Katolik millet, provided autonomy for all Roman Catholics. Each millet had its own taxation, education, and courts. Their top hierarchs were also political leaders for their flocks. For instance, the political leader of the "Roman" millet was the patriarch of Constantinople.

The "Roman" millet included all Chalcedonian Christians regardless of their ethnic background: Greeks, Serbs, Bulgars, Albanians, Montenegrins, etc. The same is with the "Armenian" millet, which included not only Armenians, but also Copts, Syrians, and other non-Chalcedonian groups. It was also managed by a patriarch. The Armenian patriarchate of Constantinople, different from the two Armenian Catholicosates, still exists as a rudiment of the millet system.

The Ottoman millet system was finalized in the nineteenth century, during the Tanzimât reforms. In the same period, the millets began a gradual transformation from the system based on religious identity to the ethnic system. Some ethnic groups from these millets emancipated from the Ottoman Empire through revolutions and wars, and established their national states. Among them were Greeks, Romanians, Bulgars, Serbs, and Montenegrins. Other peoples were less lucky and did not gain statehood for themselves, such as Copts, Syrians or Armenians. For the Armenians, their national rise ended tragically with the genocide in 1915-1917. The Habsburg Empire faced the same problem of emancipation of its ethnic minorities. Serbs, Romanians, Ukrainians, and Ruthenians looked for their own states independent from Austro-Hungary. All these emancipatory movements in the empires, where Eastern Christians constituted religious minorities, were driven by national ideology, which we will explore below as "ethnic nationalism" or the "Balkan" style of nationalism.

This style of nationalism was "derivative," in the words of Peter van der Veer. ${ }^{19}$ It had been born in the context of the Western Enlightenment and then transmitted to the Eastern context. The Western ideas about nation were disseminated through the philhellenes like Lord Byron (1788-1824), who projected to Greece his English nationalism, ${ }^{20}$ or through the Orthodox intellectuals in the diaspora, such as Adamantios Korais (1748-1833). In this

\footnotetext{
http://assets.pewresearch.org/wp-content/uploads/sites/11/2017/05/10104119/CEUP-FULL-REPORT.pdf, $12)$.

${ }^{17}$ See George Ostrogorsky, History of the Byzantine State, (New Brunswick, NJ: Rutgers University Press, 1969), 27.

${ }^{18}$ See Claudia Rapp, "Hellenic Identity, Romanitas, and Christianity in Byzantium," in Katerina Zacharia, ed., Hellenisms: Culture, Identity, and Ethnicity From Antiquity to Modernity, (Aldershot, England; Burlington, VT: Ashgate, 2008), 127-147.

${ }^{19}$ Peter van der Veer, "Nationalism and Religion," in The Oxford Handbook of the History of Nationalism, ed. John Breuilly, (Oxford: Oxford University Press, 2013), 655.

${ }^{20}$ See Maria Koundoura, The Greek Idea: the Formation of National and Transnational Identities, (London: Tauris, 2007), 64 .
} 
regard, Christos Yannaras is right when he criticizes as a Western construct the modern Greek national identity, which he calls "neo-Hellenism.", 1

The Société des observateurs de l'homme, where the idea of nation was discussed by French intellectuals, became also a place, where Korais, the only foreign member of the Society, evoked the Greek antiquity to be laid to the fundament of the new Greek nation. ${ }^{22}$ Korais explained his plan for the renewal of the Greek nation using the language of commerce - his first profession was a merchant. According to him, when Europe was emerging from barbarianism, it borrowed intellectual treasures from the ancient Greeks. Now it was time for Europe to pay the debt back, with some commission. ${ }^{23}$ Korais coined a word for this business: $\mu \varepsilon \tau \alpha \kappa \varepsilon ́ v \omega \sigma i \varsigma$. He dreamed of metakenosis as a transplantation of the European education and intellectual culture to the Greek soil.

If measured by the theories of nationalism, Korais definitely belongs to the premodern school. He traced the Greek nation to the antique primordiality. Since then, in his opinion, the Greek national culture has only downgraded: first by Romans, then in the Byzantine period, and eventually fell to lethargy under the Ottomans. Only coming back to the "golden age" of the Athenian democracy can raise the Greek nation from ashes.

In addition to the French ideas, there was a significant German input to the formation of the Orthodox nationalism. Germany's advanced classical studies were among the key factors that ignited European philhellenism in the beginning of the nineteenth century. ${ }^{24}$ German idealism inspired intellectuals in the Orthodox countries to idealize nationalism. Particularly important in the East became the German concept of language as an instrument of national formation.

Germany was politically divided during the most of the nineteenth century. As a result, it could not offer to all Germans a common social contract. Johann Gottfried von Herder (1744-1803) suggested instead consolidating the German people on the basis of common language, which exceeded political boundaries. Johann Gottlieb Fichte interpreted language as culture in a broad sense. He suggested that cultural sovereignty is even stronger than the political one and must be developed by any group of people who seek to be called a nation. $^{25}$

In line with the German ideas, the Orthodox minorities in both Ottoman and Habsburg empires began their national struggle by defining themselves culturally. Local literati standardized people's vernacular and began producing literature in spoken Greek, Bulgarian, Serbian, Romanian, and other languages. They launched campaigns to establish networks of national schools, which were to become nurseries for language and culture. They also argued against each other whose culture is higher.

Although the initial momentum that instigated the Orthodox nationalism was French, the Orthodox peoples eventually embarked on the German kind of nationalism. Rogers Brubaker from UCLA identified the difference between them as German jus sangunis - the

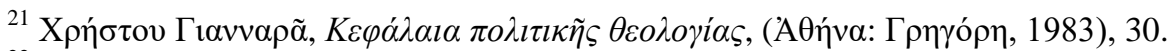

${ }^{22}$ See Olga Augustinos, "Philhellenic Promises and Hellenic Visions: Korais and the Discourses of the Enlightenment," in Zacharia, Hellenisms: Culture, Identity, and Ethnicity From Antiquity to Modernity, 169.

${ }^{23}$ See ibid., 191.

${ }^{24}$ See Glenn Most, "Philhellenism, Cosmopolitanism, Nationalism," in Zacharia, Hellenisms: Culture, Identity, and Ethnicity From Antiquity to Modernity, 151.

${ }^{25}$ See Erica Benner, "Nationalism: Intellectual Origins," in Breuilly, The Oxford Handbook of the History of Nationalism, 45-46.
} 
right of blood, versus the French jus soli - the right of land. ${ }^{26}$ This difference means that to be French required to live on the French land, while to be German meant to be born German by blood regardless of where this has happened. The difference was conditioned by the fact that France in the period of the formation of national ideas was a strong unitarian state, while Germany was an agglomerate of independent polities. The Orthodox minorities in the Ottoman and Habsburg empires were in a situation similar to the Germans. In addition, they often shared their land with the Muslim majority, whom they did not want to include to their nations. As a result, they wanted to define their nationality by blood, not by soil.

John Breuilly has defined nationalism as "a politics that seeks autonomy for the nation." ${ }^{27}$ This definition fully applies to the Eastern Christian nationalisms. The efforts of the minorities that emerged from the two empires, to define themselves through religion, culture, and education, eventually led to their struggle for political independence. Independence turned to a categorical imperative for all Orthodox nationalist movements. The German idealism was inspirational for them once again. Georg Wilhelm Friedrich Hegel, while dealing with the national issue in his own context, envisaged its destination in a unified German Nationalstaat, with a strong political authority and powerful army. For him, any accomplished nation meant a nation protected by the independent state. Only the people (Völker) with their national states had meaningful and dignified existence, deserving to be active subjects of the historical process, and not just its passive objects.

While national awakening in the West was rather secular, in the East it featured a strong religious dimension. It is noteworthy that the Orthodox Church played more important role in the national awakening on the territories of the Ottoman Empire, and was less active in the Habsburg domains. The Serbian national idea, for instance, consisted of two components: the ecclesial one generated in Belgrade (on the Ottoman territories), and the cultural, which originated from Vojvodina, a part of the Habsburg state. Similar situation was with the Romanian national idea: its cultural component came from the Habsburg's Transylvania, while its ecclesial platform was in Wallachia and Moldavia - two autonomous principalities under the Ottoman control.

The influence of the churches on the formation of the national statehood was not unilateral. National statehood affected the churches in return. It became a common understanding in the period of national struggles that the Orthodox nations should have their own autocephalous churches. The autocephaly in the nineteenth century became a form of what Peter van der Veer called "nationalization of religion." ${ }^{28}$ It turned to a synonym for national sovereignty and a necessary attribute of an accomplished nation, together with language, culture, and educational system. The first instance of this type of autocephaly was the Greek Church, which unilaterally proclaimed its independence from the church of Constantinople in 1833. Independence of the Greek Church was recognized by the church of Constantinople only in 1850. It took even longer to recognize the Bulgarian church, which proclaimed its independence in 1872. This independence was eventually accepted by Constantinople in 1945.

The procedure of declaration of autocephaly based on national identity became different from the Late Antiquity and Middle Ages. Then it was negotiated, often by political

\footnotetext{
${ }^{26}$ Rogers Brubaker, Citizenship and Nationhood in France and Germany, (Cambridge, MA: Harvard University Press, 1992).

27 John Breuilly, "Nationalism and National Unification in Nineteenth-Century Europe," in The Oxford Handbook of the History of Nationalism, ed. John Breuilly, (Oxford: Oxford University Press, 2013), 150.

${ }^{28}$ Van der Veer, "Nationalism and Religion," 657.
} 
figures, and proclaimed as a result of agreements between imperial and ecclesial authorities. In the nineteenth century, the procedure became similar to the unilateral proclamation of independent states. These states initially were not recognized by the empires, from which they separated, and existed for long time without such recognition. The same applied to autocephalies, which were first proclaimed unilaterally, and only a posteriori came to be recognized by their "mother" church.

The process, through which independent Orthodox nations obtained autocephaly for their churches, had a tremendous impact on these churches. On the one hand, they confirmed themselves as popular institutions standing by their people. On the other hand, many local Orthodox churches turned to "parcels of national identity." 29 Orthodoxy submerged to the ethnic identity, and itself became an identity. As a result, even now people, who identify themselves as Orthodox, confuse being an Orthodox with being a Serb, a Bulgarian or a Russian.

Greek, Bulgarian, Serbian, Romanian, and other Balkan nationalisms are particularist and aiming at building a single nation. There is another sort of nationalism that goes beyond only one nation. It can be called "civilizational." The subject of this nationalism is not a nation, but a civilization, which is larger and less particularist than nation. It is based on the concept of civilization as it was developed in the twentieth century by Arnold Toynbee, Quincy Wright, F.N. Parkinson and others, and had earlier precedents in the works of Oswald Spengler, who used the word "cultures" for "civilizations," as well as Lev Gumilyov with his concept of "super-ethnos." According to this concept, civilizations are "fixed organisms" 30 driven by their own values and logic. They are more social and cultural, and less geographical and linguistic entities. ${ }^{31}$ Each of them acts according to its own understanding of its place in history.

In the modern scholarship, the concept of civilization is seen with skepticism. Nevertheless, it became extremely popular in the Orthodox milieu. There are two major Orthodox editions of "civilizational nationalism": Greek and Russian ones. Both of them echo the ideas of Victor de Riqueti, marquis de Mirabeau (1715-1789), who in his treatise L'Ami des hommes (1756) defined religion as "le premier ressort de la civilization." 32 Mirabeau (by the way, a father of the famous activist of the French revolution Honore Gabriel Riqueti, comte de Mirabeau (1749-1791)) implied that civilization is both civility opposite to barbarianism and a geopolitical organism, whose energy and identity stem from religion.

The prototype of the Orthodox civilizational nationalism was produced in Greece and

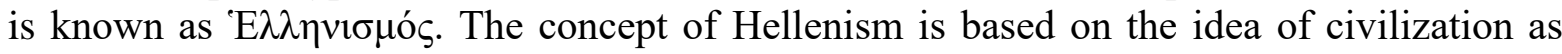
contrasting to barbarianism. It is built on dichotomization between "us" and "them." This dichotomization goes back to the fifth century BC, when Greeks were at war with Persians. The Greeks identified the Persians - "them" - as "barbarians." 33

Modern Greek nationalism claims that the historic Hellenic civilization was superior to any other civilization. According to the 2017 Pew research, Greeks are on the top of the list of the Orthodox nations who consider themselves culturally higher than other nations-

\footnotetext{
${ }^{29}$ Ibid., 658.

${ }^{30}$ Bruce Mazlish, Civilization and Its Contents, (Stanford, CA: Stanford University Press, 2004), xii.

${ }^{31}$ See Arnold Toynbee, Hellenism: the History of a Civilization, (New York: Oxford University Press, 1959), 8.

${ }^{32}$ In Mazlish, Civilization and Its Contents, 5.

${ }^{33}$ See Katerina Zacharia, "Herodotus' Four Markers of Greek Identity," in Zacharia, Hellenisms: Culture, Identity, and Ethnicity From Antiquity to Modernity, 25-27.
} 
89 percent. ${ }^{34}$ Christos Yannaras expresses this overwhelming majority of Greeks, when he claims that Hellenism is the most perfect "hypostasis" of Christianity. He draws a parallel between the cultural incarnation of Christianity in Hellenism and the incarnation of God in the person of Jesus Christ. ${ }^{35}$

Hellenism is still capable of wrestling with new barbarianism, according to Yannaras, who has identified the latter with the modern West. ${ }^{36}$ For him, the Greek civilization is built on the genuine Orthodoxy of faith, while the Western civilization, on the heretical interpretation of Christianity. ${ }^{37}$ The West alienated the personal faith of the East and transformed it to an impersonal religion. ${ }^{38}$ Even in its secularized form, the Western civilization continues to be heretical. Thus, it developed globalization as a distorted form of

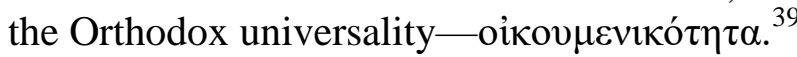

The proponents of the "Russian world"-another version of the civilizational nationalism - also criticize the modern Western "civilization." In contrast to the followers of Hellenism, however, they relativize civility and do not make references to "barbarianism." For them, there are no superior or inferior civilizations, but there are multiple civilizations that have equal rights and sovereignty. Civilizations constitute centers of gravity in the world, which thus should be multipolar. Such a world is promoted as an alternative to what is described as a uni-polar world of the American dominance. ${ }^{40}$

The "Russian world" came to identify itself with the "Russian civilization." The main forum of the "Russian world," the World Russian People's Council, at its 2001 meeting, which was also attended by President Vladimir Putin, chose as its theme "Russia: Faith and Civilization." The council concluded in its final document that Russia "is one of the pillars of the Eastern Christian world and a center of a self-sufficient civilization." This implies that the world order "should be reshaped on the principles of multipolarity... The modern world cannot be built on one civilizational model only." "The rhetoric of the council repeats the ideas of Samuel Huntington (1927-2008) ${ }^{42}$ and Aleksandr Panarin (1940-2003), who elaborated on the concept of the "Orthodox civilization."43

On the one hand, "civilizational nationalism" is still nationalism. It claims superiority for one "civilization" over others, which inevitably leads to the same conflicts and tensions that are pertinent to the classical nationalism. On the other hand, it is different and sometimes even contrary to the "ethnic nationalism," which is based on the concept of ethnos. From the perspective of the civilizational nationalism, ethnic nationalism reduces the

\footnotetext{
${ }^{34}$ Pew Research Center, "Religious Belief and National Belonging in Central and Eastern Europe," 13.

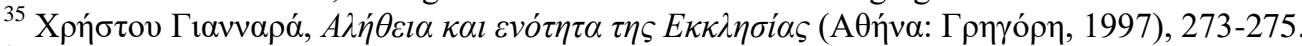

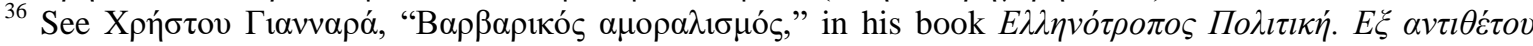

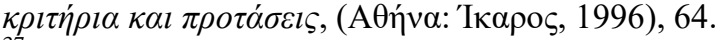

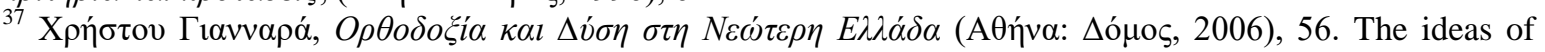
Yannaras in this point coincide with the positions of other Greek theologians, such as Nikos Matsoukas

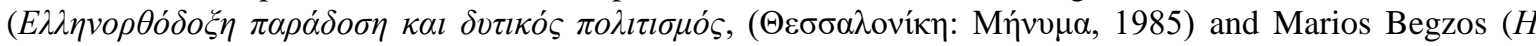

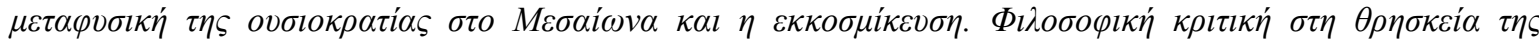

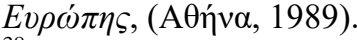

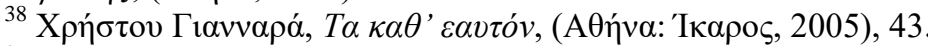

${ }^{39}$ See his lecture "Greek catholicity and Western globalism" delivered at the Foundation Anieli, Turin, Italy;

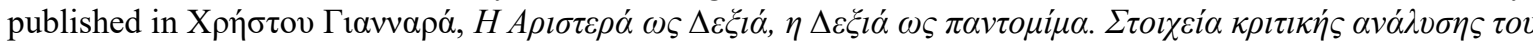

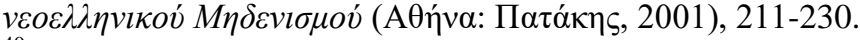

${ }^{40}$ See А.Г. Дугин, Теория многополярного мира, (Москва: Евразийское движение, 2012).

${ }^{41} \mathrm{https}: / / g o o . g l / v h 0 P W F$ [accessed April 9, 2019].

${ }^{42}$ See Samuel P. Huntington, “The Clash of Civilizations?," Foreign Affairs 72, no. 3 (August 1993): 22-49.

${ }^{43}$ А.С. Панарин, Православная циивилизация в глобальном мире (Москва: Эксмо, 2003), 210.
} 
grandeur of civilizations, which have broader horizons than nations. A zealous proponent of the Greek "civilizational nationalism" and polemicist against the ethnic nationalism, Christos Yannaras, ${ }^{44}$ despises the small size and small interests of the Modern Greek state. His ideal is Byzantium. Unlike Korais, who considered Hellenism being in the process of permanent degradation from the antique civilization, through Byzantium, to the misery of the Ottoman rule, Yannaras sees Byzantium as an apogee of Hellenism. For him, even the Ottoman Empire and modern Turkey are in some sense more heirs to Byzantium than the Greek state

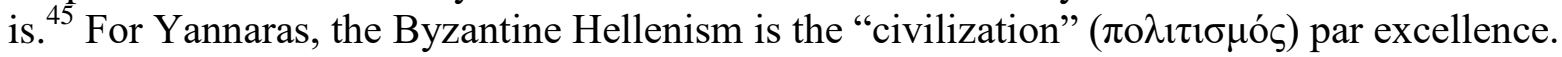

The Byzantine narrative in the Modern Greek political discourse sounds great in theory. In practice, it often led to catastrophic consequences. One of them was the so-called

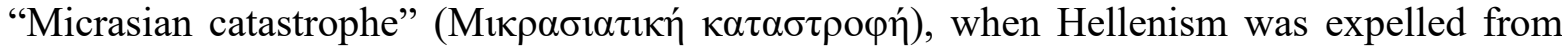
Asia Minor, after the Greek state had tried to capture territories in Anatolia in 1918-1922.

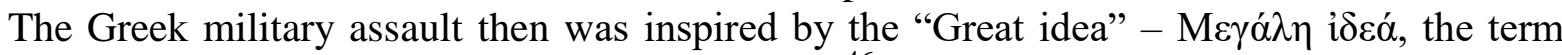
coined by the Greek nationalist Ioannis Kolettis. ${ }^{46}$ Kolettis and his fellow nationalists had envisaged a Greek state, which would include every territory with significant Greek population, primarily in Asia Minor. They thought of Greece as a continuation of the Byzantine civilization. Their main goal was to recapture Constantinople. As Ion Dragoumis put it in 1909,

"The great idea is a memory which remained, burrowed deeply and nested in the soul of the Romios, from the time that the Turks, in 1453, took the City. It is the remembrance that the Romios, with the City as capital, possessed the East in bygone years, the Eastern state with many peoples, which he inherited little by little from the ancient Romans."

Rooted in the Romanticism of the nineteenth century, ${ }^{48}$ the "Great idea" became also a fundament for Greek dictatorships during the twentieth century. In particular, Ioannis Metaxas (ruled from 1936 to 1941) presented his regime as a "Third Hellenic civilization." The first Hellenic civilization was for him embedded in the militarist societies of Macedonia and Sparta. Byzantium was a "second civilization." In contrast to the Romantic nationalists of the nineteenth century, Metaxas in his national program made references to Byzantium. These references enhanced his idea of a strong state-in the spirit of Mussolini's "lo stato totale." The Hellenism of Metaxas was anti-democratic. That is why he chose as its prototype not the Athenian democracy, but Macedonian and Spartan autocracy.

Even to a greater extent than the "Greek world," the "Russian world" as an instance of the "civilizational nationalism," became violent and war-mongering. Not surprisingly, it is also not lacking references to Byzantium. One of its proponents, Metropolitan Tikhon Shevkunov, has produced a movie, "The fall of an empire: the Lesson of Byzantium"49 where he metaphorically articulated a political program for Putin's Russia. Putin, however, while pretending to deliver a neo-Byzantine empire, in fact has produced a neo-Soviet state. It is also neo-colonial, because it tries to re-establish its control over the independent states

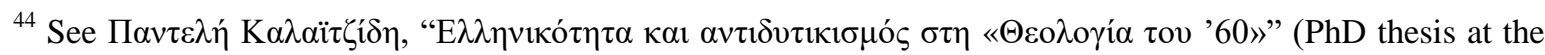
Aristotle's University of Thessaloniki, 2008).

${ }^{45}$ Yannaras told this to the author of this article during our trip to Cappadocia together with Ecumenical Patriarch Bartholomew in 2007.

${ }^{46}$ See Richard Clogg, A Concise History of Greece, (Cambridge: Cambridge University Press, 1992), 48.

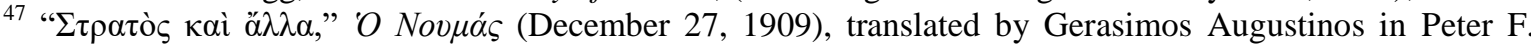
Sugar, ed., Eastern European Nationalism in the Twentieth Century, (Lanham, MD: American University Press, 1995), 164.

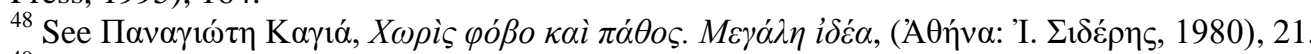

${ }^{49}$ https://goo.gl/bn1dX9 [accessed April 9, 2019].
} 
that emancipated from the Soviet Union. The wars against Georgia in 2008 and Ukraine since 2014, conflicts in Transnistria and Nagorno-Karabakh, provocations on the borders with the Baltic states - all these are the results of the Russian dreams about Byzantium.

The policies of the Russian Orthodox Church cohere, and enhance, the policies of the Russian state. Sometimes the former antecede the latter. An official speaker of the Moscow Patriarchate at that time, Fr. Vsevolod Chaplin, was among the earliest voices that urged the Russian intervention to Ukraine in the wake of the Revolution of dignity in Kyiv. He stated in his comment to the news agency Interfax on March 1, 2014:

"Back in 1995, the World Russian People's Council declared that the Russian people is a divided nation on its historical territory, which has the right to be reunited in a single state body, which is a generally accepted rule of international politics... We hope that the mission of Russian soldiers to protect freedom and identity of these people and their very life will not meet fierce resistance...",50

He added that military intervention would secure the "civilizational choice" for the Russian language and prevent the Ukrainians from aligning with the West. This statement was made before the Russian military occupied Crimea and invaded Donbas, when only a few believed that the Russian aggression against Ukraine would be possible. Fr. Chaplin's statement referred to the idea of civilization, which, in his opinion, had right to be consolidated on the basis of common values, and with the use of military force. This exactly happened with the annexation of Crimea and the following war in the Donbas, as a result of the Russian "civilizational nationalism."

\section{CONCLUSION}

Nationalism can be "ethnic" and "civilizational"-in other words, "republican" and "imperial." Both forms can be irenic or violent. Irenic ethnic nationalism can help build nations and liberate them from the yoke of empires. Its violent versions can ignite conflicts and wars even between the peoples who share the same religion. An eloquent example of this are the Balkan wars in 1912-13. Four Orthodox states that had secured for themselves independence from the Ottoman empire: Bulgaria, Greece, Montenegro, and Serbia - formed a Balkan league and began a military campaign against Turkey to grab some more territories. When they captured most of the European part of Turkey, they began quarrelling among themselves. Bulgaria attacked Serbia and Greece over the disputed territories in Macedonia, was repelled and additionally invaded by Romania. Thus, the Orthodox nations, who had fought for the same cause of national liberation from the Ottoman empire, ended in fighting their brethren Orthodox for national causes. Civilizational nationalism can be also violent. It is quite hostile to ethnic identity, which it considers inferior to what it calls civilization. Effectively this sort of nationalism supports empires and quasi-empires, such as Putin's Russia. It is imperial and colonial by its nature.

${ }^{50}$ https://goo.gl/crocPA [accessed April 9, 2019]. 


\section{BIBLIOGRAPHY}

[1] ${ }^{1}$ See Peter Burke, "Nationalism and Vernaculars, 1500-1800," in ibid., 21.

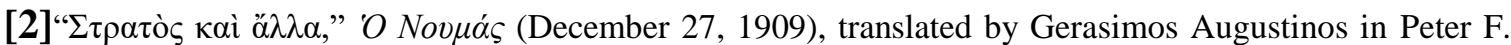
Sugar, ed., Eastern European Nationalism in the Twentieth Century, (Lanham, MD: American University Press, 1995), 164.

[3] Adrian Hastings, The Construction of Nationhood: Ethnicity, Religion, and Nationalism, (Cambridge; New York: Cambridge University Press, 1997),

[4]Arnold Toynbee, Hellenism: the History of a Civilization, (New York: Oxford University Press, 1959), 8.

[5]Benedict Anderson, Imagined Communities: Reflections on the Origin and Spread of Nationalism, (London; New York: Verso, 2006)

[6]Bruce Mazlish, Civilization and Its Contents, (Stanford, CA: Stanford University Press, 2004), xii.

[7]Claudia Rapp, "Hellenic Identity, Romanitas, and Christianity in Byzantium," in Katerina Zacharia, ed., Hellenisms: Culture, Identity, and Ethnicity From Antiquity to Modernity, (Aldershot, England; Burlington, VT: Ashgate, 2008), 127-147.

[8]Eric J. Hobsbawm, Nations and Nationalism Since 1780: Programme, Myth, Reality, (Cambridge; New York: Cambridge University Press, 1990).

[9]Erica Benner, "Nationalism: Intellectual Origins," in Breuilly, The Oxford Handbook of the History of Nationalism, 45-46.

[10] Erica Benner, "Nationalism: Intellectual Origins," in John Breuilly, ed., The Oxford Handbook of the History of Nationalism, (Oxford: Oxford University Press, 2013), 39.

[11] Ernest Gellner, Thought and Change, (Chicago: University of Chicago Press, 1965),

[12] George Ostrogorsky, History of the Byzantine State, (New Brunswick, NJ: Rutgers University Press, 1969), 27.

[13] Glenn Most, "Philhellenism, Cosmopolitanism, Nationalism," in Zacharia, Hellenisms: Culture, Identity, and Ethnicity From Antiquity to Modernity, 151.

[14] Herodotus, Histories, 8.144.1-3, transl. by Aubrey de Sélincourt, (London: Penguin, 2003).

[15] http://www.constitution.org/jjr/corsica.htm [accessed April 9, 2019].

[16] https://goo.gl/bn1dX9 [accessed April 9, 2019].

[17] https://goo.gl/vh0PWF [accessed April 9, 2019].

[18] Hugh Seton-Watson, Nations and States: an Enquiry Into the Origins of Nations and the Politics of Nationalism, (Boulder, CO: Westview Press, 1977).

[19] John Breuilly has called it "the most important political ideology of the modern era." John Breuilly, "Reflections on Nationalism", in Stuart Woolf, ed., Nationalism in Europe, 1815 to the Present: a Reader, (London: Routledge, 1996),

[20] John Breuilly, "Nationalism and National Unification in Nineteenth-Century Europe," in The Oxford Handbook of the History of Nationalism, ed. John Breuilly, (Oxford: Oxford University Press, 2013),

[21] Katerina Zacharia, "Herodotus' Four Markers of Greek Identity," in Zacharia, Hellenisms: Culture, Identity, and Ethnicity From Antiquity to Modernity, 25-27.

[22] Maria Koundoura, The Greek Idea: the Formation of National and Transnational Identities, (London: Tauris, 2007), 64.

[23] Memory in Jewish, Pagan, and Christian Societies of the Graeco-Roman World, (London; New York: T \& T Clark International, 2004).

[24] Murray Greensmith Forsyth, Reason and Revolution: the Political Thought of the Abbé Sieyes, (Leicester; New York: Leicester University Press; Holmes \& Meier, 1987), 76.

[25] Olga Augustinos, "Philhellenic Promises and Hellenic Visions: Korais and the Discourses of the Enlightenment," in Zacharia, Hellenisms: Culture, Identity, and Ethnicity From Antiquity to Modernity,

[26] Peter van der Veer, "Nationalism and Religion," in The Oxford Handbook of the History of Nationalism, ed. John Breuilly, (Oxford: Oxford University Press, 2013), 655.

[27] Pew Research Center, "Religious Belief and National Belonging in Central and Eastern Europe," 13.

[28] Richard Clogg, A Concise History of Greece, (Cambridge: Cambridge University Press, 1992), 48. 
[29] Rogers Brubaker, Citizenship and Nationhood in France and Germany, (Cambridge, MA: Harvard University Press, 1992).

[30] Samuel P. Huntington, "The Clash of Civilizations?," Foreign Affairs 72, no. 3 (August 1993): 22-49.

[31] Susan Reynolds, Kingdoms and Communities in Western Europe, 900-1300, (Oxford; New York: Oxford University Press, 1984).

[32] Yannaras told this to the author of this article during our trip to Cappadocia together with Ecumenical Patriarch Bartholomew in 2007.

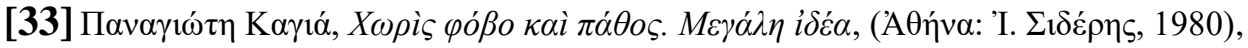

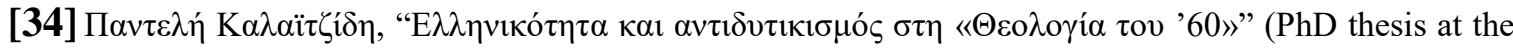
Aristotle's University of Thessaloniki, 2008).

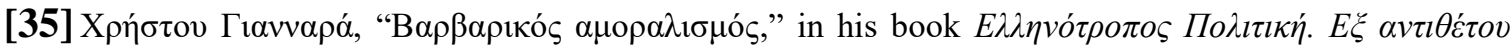

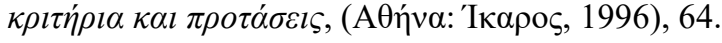

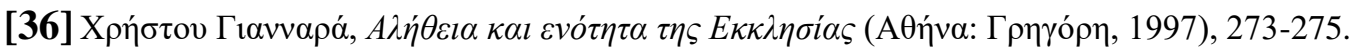

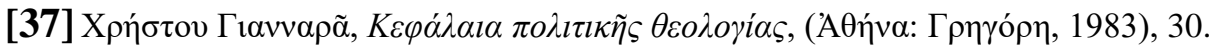

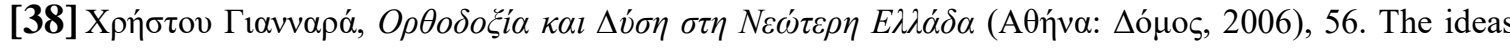
of Yannaras in this point coincide with the positions of other Greek theologians, such as Nikos

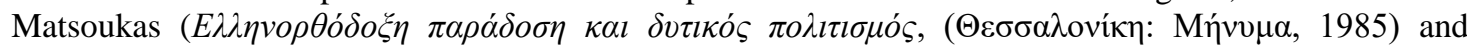

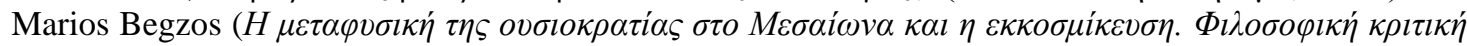

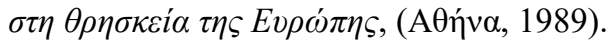

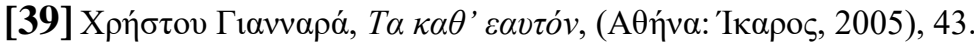

[40] А.Г. Дугин, Теория многополярного мира, (Москва: Евразийское движение, 2012).

[41] А.С. Панарин, Православная циивилизаџия в глобальном мире (Москва: Эксмо, 2003), 210. 